\title{
Continu werken aan continuïteit*
}

$\mathrm{Nu}$ omzetgroei van veel Nederlandse ondernemingen uitblijft, resultaten en rentabiliteit voor vele sectoren beneden die van het wereldgemiddelde liggen, het aantal faillissementen in 1981 ruim driemaal zo hoog is als in 1975 , en de bijzondere voorzieningen bij de banken in die periode eveneens verdrievoudigd zijn, is het thema van vandaag actueel en belangrijk.

Izeboud heeft een uitvoerige, volledige en grondige uiteenzetting gegeven, waarmee ik in principe kan instemmen.

Mijn reactie bevat dan ook slechts enige architectonische kritiek, wijst op enkele schoonheidsgebreken, en geeft aan welke van de door Izeboud genoemde factoren essentieel zijn voor continuiteit en daarmede dan tegelijk voor de bepaling of er een dreiging is van discontinuiteit.

Ik wil me daarbij beperken tot 3 punten, belicht vanuit de invalshoek van management, dus als het goed is met een wat pragmatische inslag.

1. Wanneer is er sprake van een goed financieel-economisch fundament voor continuïteit?

2. Welke factoren beïnvloeden continuïteit?

3. Welk soort informatie- en besluitvormingsproces is nodig om de basisfactoren voor continuïteit intact te houden?

\section{Rentabiliteit en continuiteit}

Eerst dan de vaststelling wanneer er sprake is van een goed financieeleconomisch fundament voor continuiteit.

Er is sprake van continuiteit, zo zegt Izeboud, zolang de onderneming erin slaagt een zodanig waardeverschil tussen de in- en verkoopmarkten te creëren en te realiseren dat daaruit alle bij de onderneming betrokkenen een adequate beloning voor hun diensten verschaft kan worden. Wanneer en zolang echter betrokkenen genoegen nemen met een lagere dan voor hen adequaat geachte beloning, is er van discontinuitteit nog geen sprake. Dit is wel het geval wanneer er acties van een of meer groepen van betrokkenen ontstaan.

Ten aanzien van een van de groepen betrokkenen, namelijk de vermogensverschaffers, zou ik hetgeen Izeboud heeft gesteld willen aanvullen, namelijk dat een voldoende rentabiliteit op het eigen vermogen moet worden behaald. Dit wil zeggen dat behaald moet worden een rentabiliteit gelijk 
aan de rentevergoeding aan verschaffers van vreemd vermogen vermeerderd met een risico-opslag! ${ }^{1}$

Deze rentabiliteit is nodig om een adequaat dividend te betalen, om vernieuwingen, ook sociale en maatschappelijke vernieuwingen, uitbreidingen en groei van het bedrijf, te financieren. Al mogen dan de niet-contractuele vermogensverschaffers genoegen nemen met een lagere of geen beloning, een blijvend niet-voldoende rentabiliteit vormt een rode lamp, een risicofactor voor continuiiteit en vraagt, nee eist, acties van het management. Het lijkt me noodzakelijk dat deze op zich oude en bekende doelstelling zwaar onderstreept wordt. Dit is temeer nodig omdat belangrijke groepen in onze Nederlandse samenleving van mening zijn dat bepaalde acties van management pas mogen worden genomen wanneer de onderneming verliesgevend is geworden.

\section{Basisfactoren voor continuïteit}

Wat bepaalt de basis welke continuïteit oplevert? Welke factoren zijn succesbepalend voor de onderneming.

Een onderzoek van $\mathrm{Hall}^{2}$ bij een aantal Amerikaanse ondernemingen leverde op dat het consistent volgen van een der volgende basis-strategieën bepalend is voor een blijvend leidende positie in resultaten, rentabiliteit, technologie en groei, juist ook in omstandigheden van stagnerende markten en inflatoire kostenstijgingen.

Twee basis-strategieën komen uit het onderzoek naar voren.

De eerste is:

Realiseer, in vergelijking met de concurrentie, de laagste kostprijs, vergezeld van een aanvaardbare kwaliteit en een prijspolitiek welke leiden tot groei van volume en marktaandeel.

De tweede is:

Realiseer, in vergelijking met de concurrentie, een exclusieve produkt/ kwaliteitsdifferentiëring, vergezeld van een aanvaardbare kostprijs en een prijspolitiek, welke leiden tot het realiseren van volume en marges, op basis waarvan ge-reïnvesteerd kan worden in een verdere differentiëring en segmentering.

De eerste strategie richt zich op het leveren van eenzelfde produkt, maar met een lagere kostprijs. We kunnen denken aan bulk-produkten.

De tweede strategie richt zich op het leveren van een beter produkt, zoekt een segment, een niche in de markt. Dit betekent differentiatie van de overige produkten. We kunnen denken aan de segmentatie in de margarinemarkt.

Het gemeenschappelijke in beide strategieën is, dat de onderneming, in vergelijking met de concurrentie, een voordeel moet realiseren, een sustainable competitive advantage, een blijvend concurrentie-voordeel, leidend tot betere resultaten dan de concurrenten en tot een betere, sterkere basis voor continuïteit. 
Dit betekent, en dit vind ik essentieel, dat het management primair extern, op de markt, op consumenten en afnemers, op de concurrenten, nationaal en internationaal, op de omgeving in brede zin gericht moet zijn. De positionering van het produkt in de markt moet daarna intern vertaald worden in de structuur en organisatie van de onderneming en niet omgekeerd.

De onderneming zal daarbij kijken naar bestaande inkoopmarkten, bestaande concurrenten en bestaande technologieën, maar vooral ook naar nieuwe inkoopmarkten, nieuwe concurrenten en nieuwe technologieën. Het management zal continu, in samenhang met nieuwe concepten voor de markt, trachten zelf trend-breuken te realiseren in de technologie. Het management moet er echter ook op bedacht zijn dat huidige of nieuwe concurrenten dit ook doen. ${ }^{3}$

General Electric was twaalf jaar geleden onbetwist leider in de vacuümbuizen-technologie, maar een belangrijk stuk discontinuitteit trad op toen onverwacht nieuwe concurrenten met de transistor-technologie kwamen. De tweedelige aluminium-bus was een grote schok voor de traditionele blikfabrikanten. De komst van de tetra-pakken zorgde voor een tweede. De Amerikaanse banken werden opgeschrikt door het optreden van het warenhuis Sears Roebuck als nieuwe concurrent.

Waarden en normen van consumenten en afnemers veranderen continu. Het betekent vooral ook aandacht voor politieke, sociale en culturele ontwikkelingen. De komst van meer dan een half miljoen vreemdelingen in Nederland bijvoorbeeld betekent nogal wat.

Naast de groepen direct betrokkenen in de onderneming zien we een toenemend aantal groepen in de samenleving die, ongevraagd, zichzelf beschouwen als participanten, als stake-holders in de onderneming. Vaak voeren zij zeer ongenuanceerd en heftig actie tegen bedrijven en trachten invloed uit te oefenen op het competitive advantage. ${ }^{4}$

Tenslotte hoort het management in toenemende mate ook rekening te houden met voorziene en vooral ook onvoorzienbare acties van de overheid. Een structurele verlaging van E.E.G.-exportrestituties betekende mede discontinuïteit voor de Nederlandse export van ham in blik naar de Verenigde Staten.

De aandacht van het management zal primair naar buiten gericht moeten zijn, de interne vertaling in structuur en organisatie moet in lijn zijn met de externe positionering.

Ook hier weer is het van het grootste belang de kosten van de structuur en organisatie te bepalen, in relatie tot die van de concurrenten, nationaal en internationaal.

Bij de interne vertaling weer een externe invalshoek. De eigen acties zullen bovendien weer reacties opleveren van concurrenten en stake-holders. 


\section{Intact houden van continuïteit}

Welk soort informatie en welk soort besluitvormingsproces zijn nodig om de basis voor continuïteit intact te houden?

Om tot een goede strategie, tot strategische beslissingen en tot een geïntegreerd samenstel van acties te komen, welke leiden tot een competitive advantage, is goed management nodig. Informatie over de genoemde externe en interne ontwikkelingen, en een goede analyse zijn onontbeerlijk. Maar niet alleen analyse en informatie, maar vooral ook gezond verstand, visie, overtuiging, creativiteit en intuitie vormen mede de basis om tot een concurrentie-voordeel te komen.

Informatiesystemen leggen zich vooral toe op het rapporteren van bedrijfsresultaten en zijn vaak partieel van opzet en ex-post gericht. Bij de strategische besluitvorming is juist de ex-ante bepaling van ontwikkelingen in de toekomst van belang. ${ }^{5}$

Strategische informatie zal veel aandacht moeten schenken aan het voorzien van kansen en bedreigingen. Niet slechts op basis van bestaande trends extrapoleren, maar met visie schouwen in de toekomst en trendbreuken proberen te zien aankomen. ${ }^{6} \mathrm{Er}$ is veel meer nodig dan een informatiesysteem kan opleveren. Vaak moet onvolledige informatie worden gebruikt.

Essentieel is het strategisch besluitvormingsproces, op grond waarvan de strategische beslissingen worden genomen. Verder leren we in de praktijk, dat het even essentieel is om te komen tot realistische actieplannen. Niet alleen actieplannen met betrekking tot bijvoorbeeld nieuwe machines, maar mogelijk ook met betrekking tot noodzakelijke veranderingen van een cultuur van de onderneming. ${ }^{7}$

Teveel blijven meer-jarenplannen verplichte papieren exercities, te vaak zijn actieplannen niet realistisch.

Samenvattend: Niet-werken aan het intact houden van de continuïteit betekent een dreiging van discontinuïteit.

Voor de kwaliteit van het management is opleiding een belangrijke factor. Daarbij pleit ik ervoor dat de opleiders, de economische faculteit en de Universiteit, nauw samenwerken met het bedrijfsleven, om te komen tot een opleidingsprogramma gericht op de eisen en mogelijkheden van morgen.

De accountant, als deskundige op het gebied van de bewaking van kapitaal en vermogen, zal als onderdeel van zijn normale functie-uitoefening zich ervan moeten vergewissen dat het management periodiek een adequaat meer-jarenplan maakt en een consistent netwerk van acties ontwikkelt en uitvoert.

Hij zal een toetsing moeten uitvoeren op de essentiële elementen van stategie en actieplan, en trachten op grond daarvan een constructieve bijdrage te leveren aan de positie van de onderneming in de toekomst. Die constructieve bijdrage wordt geleverd als de accountant zich niet alleen 
richt op de instandhouding van vandaag, maar ook op die van morgen, of anders gezegd: een bijdrage levert aan de groei van kapitaal en vermogen. Excelleren in deze groei-bijdrage zal de betrokken accountant een competitive advantage geven.

Ik hoop en vertrouw dat ook in de komende jaren onze opleiding veel van zulke excellerende accountants zal opleveren.

Universiteit, stake-holders, accountants en management hebben zo allen een boeiende opgave, waar een wijs hart voor bekomen moet worden. ${ }^{8}$ Dat betekent op een schrandere, kloekzinnige wijze onze dagen tellen, in de wetenschap van de Spreukendichter ${ }^{9}$ dat

de Wijsheid woont bij de schranderheid en kennis verkrijgt door overleggingen.

\section{Literatuurlijst}

1. Rapport bedrijfseconomische normen inzake de continuitteit van ondernemingen. L. Traas en L. E. H. Vredevoogd, 1973, pag. 16.

2. Survival strategies in a hostile environment. W. K. Hall, Harvard Business Review, September-October 1980 .

3. A call for vision in managing technology, by Richard N. Foster, Business week, May 24 1982.

4. Who's butting into your business, by J. R. Emshoff and R. E. Freeman, The Wharton Magazine, 1979 page $44-48,58,59$.

5. The advent of strategic information systems by C. Stiles, Managerial Planning, September/October 1980 .

6. Waarschuwingssignalen voor de ondernemer. Dr. ir. J. G. Wissema in De praktijk van strategische beleidsvorming, pag. 74 .

7. Implementing Strategy, P. J. Stonich. 1982 Ballinger Publishing Company, page 32 - 48

8. 25 jaar accountancy, J. Nathans, laatste alinea.

9. Spreuken $8-12$. 